\title{
Social Entrepreneurship in Turkey: A Content Analysis Assessing Ashoka Fellows
}

\author{
Burcu INCI
}

\begin{abstract}
Social entrepreneurship is growing rapidly with increased attention from government, businesses, non-governmental organizations (NGOs), public, universities and media. It is an emerging area of investigation within the entrepreneurship and not-for-profit literatures. In developing countries such as Turkey, the term has been revealed especially after 2000s. There is only little research about this concept in Turkey, so this paper aims to fill this gap and introduce social entrepreneurs in Turkey. Ashoka is the largest network of social entrepreneurs worldwide with nearly 3,000 fellows in 70 countries. Ashoka fellows have innovative solutions to social problems and the potential to change patterns across society. So I have investigated Ashoka fellows in Turkey, because they are leading social entrepreneurs in this country. At the end of the study it has been understood that it is not possible to say developed countries have more social entrepreneurs than underdeveloped countries and vice versa. In the world, most widespread fields of social entrepreneurs are economic development $(\% 19,8)$, human rights $(\% 18)$, and civic engagement $(\% 17,2)$. In contrast; civic engagement $(\% 40)$ is very dominant in Turkey. It is interesting that there is not any social entrepreneur working on learning/education in Turkey while world percentage of this field is \%16,2. Another result of this study is that economic stability affects number of social entrepreneurs at least in Turkey. The findings about gender of social entrepreneurs in Turkey are surprising. Because number of women and men social entrepreneurs in Turkey are almost equal although there are very few women entrepreneurs against men in Turkey's economic enterprises.
\end{abstract}

Index Terms-Ashoka, Ashoka fellows in Turkey, social entrepreneurship, social entrepreneurs.

\section{LITERATURE REVIEW}

\section{A. Social Entrepreneurship}

Much of the literature on social entrepreneurship debate definitional and domain issues with a heavy focus on conceptual over empirical research. Therefore there is a confusion resulting in no unified definition [1]. Although problems that governments are unable to solve are increasing, and social entrepreneurship is as important as commercial entrepreneurship; adequate numbers of researches have not been made concerning social entrepreneurship [2]. The term "intrapreneur" and "corporate entrepreneur" are used synonymously and generally refer to corporate managers who

Manuscript received March 29, 2016; revised July 14, 2016.

Burcu İNCI is with the Nisantaşı University, Faculty of Economics, Administrative and Social Sciences, İstanbul, Turkey (e-mail: burcu.inci@nisantasi.edu.tr). exhibit entrepreneurial spirit in the course of carrying out their work. But these terms do not tend to denote a social orientation unlike the term "social entrepreneur" [3]. According to Peter Drucker social entrepreneurship may become more important than commercial entrepreneurship in the future [4].

Social mission is explicit and central for social entrepreneurial organizations. On the funding side, social entrepreneurs look for innovative ways to assure that their ventures will have access to resources [5]. The greatest challenge in understanding social entrepreneurship lies in defining the "social" concept. Entrepreneurship in the business sector also has a social aspect [6]. In fact there isn't a thing such as "antisocial entrepreneurship". A lot of people are employed and taxes are being paid by the help of commercial entrepreneurship. These are important social functions. Social entrepreneurship creates new models for meeting the fundamental needs that are not met by existing economic and social institutions [7].

According to Global Entrepreneurship Monitor (GEM) "social entrepreneurship is any attempt at new social enterprise activity or new enterprise creation, such as self-employment, a new enterprise, or the expansion of an existing social enterprise by an individual, team of individuals or established social enterprise, with social or community goals as its base and where the profit is invested in the activity or venture itself rather than returned to investors" [8]. Three layers of social entrepreneurship are: (1) integrated social entrepreneurship where profit making corporate activity also produces social benefits, (2) reinterpretation involving cost-cutting or revenue diversification of the non-profit organization, and (3) complementary social entrepreneurship where nonprofit organizations undertake profit-seeking activities to cross subsidize their social mission [9].

Social entrepreneurship applies the ideology of private business to social causes and encourages "business-like" solutions to social problems. Social entrepreneurship seeks social, rather than personal returns on their entrepreneurial activities [10]. Social entrepreneurship is a voluntarily kind of organization that provides services to the society for free [11].

Social entrepreneurship appears when someone or a group involves such things: (1) the purpose is to create a social utility; (2) there is a capacity for transforming valuable opportunities to advantages; (3) there is an innovation in creating a social utility and distributing it; (4) they are volunteer for accepting a risk above the average in creating a social utility and distributing it; and (5) they don't dread of scarce resources while running after their social enterprise [12]. Social entrepreneurship is devoted to help and 
participation relevant to social issues. Volunteerism is the main topic of this kind of entrepreneurship [13].

Social enterprises need to be distinguished from other socially-oriented organizations and initiatives that bring benefits to communities but which are not seeking to be "businesses" and they are more likely to remain dependent on gifts and grants [14]. Social entrepreneurship creates an innovative social value which can appear in public sector, private sector or NGOs [15]. They can be summarized as follows [16]:

Social Enterprises in Private Sector: Working in private sector create the advantage of planning, focusing on profit and innovations for the social entrepreneur who can also gain experience in market research and feasibility activities and learn the systematic process of idea generation and selection. Modern business trends can be applied more freely and the atmosphere is more democratic and more open to new ideas.

Social Enterprises in NGOs: For a long time "social entrepreneurship" is called as "NGOs," "third sector" and had no special name for itself. A lot of social movement organization contained the creative and passionate works of people who fits entrepreneurship soul. The entrepreneurship trend in NGOs increased the competition among them for finding funds.

Social Enterprises in Public Sector: There are important political and managerial differences between public enterprises and private enterprises. For example public enterprises have more difficulty in adapting changes; they are less innovative and have less freedom. So it is more difficult for social enterprises to appear in public sector. Another reason for this is noncompetitive nature of public sector.

In our world the cliff among rich and poor becomes deeper every day. So making social entrepreneurship widespread is very critical. Social entrepreneurship determines a social need and provides a social utility for poor by exposing a potential with a small capital [17]. There are five characteristics that make social entrepreneurs different from business entrepreneurs [18]: social entrepreneurs acting as change agents in the social sector by (1) adopting a mission to create and sustain social value; (2) recognizing and relentlessly pursuing new opportunities to serve that mission; (3) engaging in a process of continuous innovation, adaptation, and learning; (4) acting boldly without being limited by resources in hand; and (5) exhibiting heightened accountability to the constituencies served and for the outcomes created.

Consumers buy goods because of the utilitarian and nonutilitarian (emotional, social etc.) benefits. In social enterprises, where the trading organization is able to help people in need as a consequence of consumers' purchases of their product, the intangible rewards of helping are likely to play role in motivating consumers to buy. So if we compare social enterprises with economical enterprises, consumers have more motives for purchasing [19]. There are also similar characteristics between social enterprises and economic enterprises such as [20]: Generally their efforts are made for innovative products and services that are produced locally; using a lot of approaches for finding applicable methods and making many trials; and both of them have leaders who are committed to their enterprises.
Muhammad Yunus, founder of the Grameen Bank and father of microcredit, provides a classic example of social entrepreneurship. The stable but unfortunate equilibrium he identified consisted of poor Bangladeshis' limited options for securing even the tiniest amounts of credit. Unable to qualify for loans through the formal banking system, they could borrow only by accepting exorbitant interest rates from local moneylenders. Yunus confronted the system, proving that the poor were extremely good credit risks by lending $\$ 27$ from his own pocket to 42 women from the village of Jobra. The women repaid the entire loan. Yunus found that with even tiny amounts of capital, women invested in their own capacity for generating income [21]. Organizational structures that are set up to undertake social enterprises can be classified in three titles [22]:

Leveraged non-profits: In this model, the entrepreneur sets up a not-for-profit organization to drive the adoption of an innovation. In doing so, he or she gathers the commitment of a cross section of society, including private and public organizations as well as volunteers. The organization depends on outside funding for its survival in the form of grants and donations, but its longer-term sustainability is enhanced because of the commitment of a multiplicity of actors to the vision and objectives of the organization, which often ends up transcending the organization itself.

Hybrid not-for-profits: Here, the entrepreneur sets up a not-for-profit but the model includes some degree of cost-recovery through the sale of goods and services to a cross section of partnering institutions - public and private, as well as to target population groups. However, to be able to sustain the transformational activities in full and address the needs of clients, most of who are poor or otherwise marginalized from society, the entrepreneur must mobilize other sources of funds. Those funds can be in the form of grants or loans.

Hybrid for-profits or social businesses: In this model, the entrepreneur sets up a business to drive the transformational change. While profits are generated, the main aim is not to maximize financial returns for shareholders but to grow the social venture and reach more people in need effectively. Revenues beyond costs are reinvested in the enterprise in order to fund expansion.

The entrepreneur should be considered as a social entrepreneur as long as the entrepreneur has the entrepreneurial characteristics and leading an organization with a social mission, regardless of whether it is a non-profit organization or hybrid organization, Therefore, it is possible to actively pursue social entrepreneurship activities while having financial goals as well [23].

Social entrepreneurship happens across levels and between actors, drawing on markets, movements and alliances as templates for success. So Montgomery, Dacin and Dacin [24] propose the concept of "collective social entrepreneurship" in an effort to understand the multitude of external actors that often collaborate to form and support entrepreneurial ventures.

\section{B. Social Entrepreneurs}

The term "social entrepreneur" was coined in the late 1990s to describe individuals who exhibit vision, energy, and ability to develop new ways of alleviating social problems in their 
communities [25]. Social entrepreneurs are typically not socially responsible business leaders, directors of enterprises promoting sustainable development, managers of established non-profit organizations [26]. Social entrepreneurs are individuals with innovative solutions to society's most pressing social problems. They are ambitious and persistent, tackling major social issues and offering new ideas for wide-scale change. Rather than leaving societal needs to the government or business sectors, social entrepreneurs find what is not working and solve the problem by changing the system, spreading the solution, and persuading entire societies to move in different directions [27].

Social entrepreneurs are defined as individuals or private organizations that take the initiative to identify and address important social problems in their communities. This definition focuses on the initial stages of developing new programs and includes specific activities, such as raising awareness, identifying and acquiring resources, coordinating actions with other agencies, and setting up programs in ways that are consistent with modern management strategies. The term "private" comprises both for-profit and nonprofit organizations [28].

The social entrepreneur is a mission-driven individual who uses a set of entrepreneurial behaviors to deliver a social value to the less privileged, all through an entrepreneurially oriented entity that is financially independent, self-sufficient, or sustainable [29].

When an economic entrepreneur fails it is detrimental only for him/her and his /her family, but when a social entrepreneur fails, it may be detrimental for all society. The process that social entrepreneur faces is as follows [30]: He determines a problem, produces a new project, develops a new method, finds a new resource, and makes the project sustainable.

Public entrepreneur is who prepare a public organization for changing the existing model in developing limited public resources. Social entrepreneurs are different from public entrepreneurs for these reasons [31]: Social entrepreneurs are normal citizens, they are not public officials, they aim to increase public awareness on a general public sector, and hope that increased public interest will produce a solution. Unfortunately, until recently, social enterprises were not taken as seriously as they should be as an important driver of social progress. People tended to focus on government and markets as the main social forces, treating the "third sector" as marginal, rather than as a potential major engine for progress [32].

Even though they are differently motivated, the challenges and problems social entrepreneurs face resemble those faced by economic entrepreneurs. They face challenges of identifying opportunities and needs, planning, acquiring support information and resources, marketing and creating demand, and constructing organizational frameworks [33].

Most of the characteristics of successful social entrepreneurs are the same as entrepreneurs' of private sector. They are ambitious, have a promotive mission and communicate through this mission. But their vision is one that adds value to social needs. Their network development accompanies with trust, transparency and cooperation, this means social capital. If so, there are more social entrepreneurs in countries in which social capital is more developed [34]. In recent literature, the focus has shifted from analyzing the characteristics of the entrepreneur to examining the organizational and social environment in which the entrepreneur operates. Social entrepreneurs do not act alone; they develop and then act within an organizational context. Therefore, entrepreneurship should be viewed as the behavioral characteristics of an organization [35].

Differences among social entrepreneurs and economic entrepreneurs can be classified under three titles [36]: (1) According to ethical values of social entrepreneurs public money should be spend fairly. Economic entrepreneurs can also have ethical values but they are not as strong as social entrepreneurs'. (2) Second difference comes from their goals and missions. Their mission is for meeting the social needs rather than shareholder value or profit. (3) It is possible for an entrepreneur to be successful without innovative methods, but social entrepreneurs use innovative methods almost every time.

TABLE I: NUMBER OF ASHOKA FELLOWS WORLDWIDE

\begin{tabular}{|c|c|}
\hline Country & $\begin{array}{c}\text { Number of } \\
\text { Fellows }\end{array}$ \\
\hline $\begin{array}{l}\text { Belize, Benin, Botswana, China, Guinea-Bissau, Hong } \\
\text { Kong S.A.R. China, Iceland, Italy, Latvia, Libya, } \\
\text { Malawi, Niger, Portugal, United Arab Emirates }\end{array}$ & 1 \\
\hline $\begin{array}{l}\text { Haiti, Kuwait, Mozambique, Netherlands, Saudi } \\
\text { Arabia, Singapore, Timor-Leste, Togo, Tunisia }\end{array}$ & 2 \\
\hline Afghanistan, Denmark, Morocco, Zambia & 3 \\
\hline Austria, Ivory Coast, Japan, Nicaragua, Rwanda & 4 \\
\hline Philippines & 5 \\
\hline $\begin{array}{l}\text { Cameroon, Gambia, Guatemala, Norway, South Korea, } \\
\text { Sweden, Tanzania }\end{array}$ & 6 \\
\hline Ghana, Lebanon & 7 \\
\hline Belgium, El Salvador, Israel, Jordan, Lithuania & 8 \\
\hline Palestinian Territory & 9 \\
\hline Switzerland & 10 \\
\hline Ireland & 12 \\
\hline Costa Rica, Mali & 13 \\
\hline Paraguay, Zimbabwe & 15 \\
\hline Slovakia, Sri Lanka & 19 \\
\hline Uruguay & 20 \\
\hline Bolivia & 23 \\
\hline Uganda & 24 \\
\hline Senegal & 25 \\
\hline Venezuela & 26 \\
\hline Czech Republic, Spain & 28 \\
\hline United Kingdom & 29 \\
\hline Ecuador & 31 \\
\hline Hungary & 33 \\
\hline Burkina Faso & 34 \\
\hline Turkey & 35 \\
\hline Kenya & 37 \\
\hline Peru & 39 \\
\hline Nepal & 41 \\
\hline Chile & 44 \\
\hline Egypt, Pakistan & 45 \\
\hline France & 46 \\
\hline Canada & 51 \\
\hline Colombia, Germany & 56 \\
\hline Argentina, Bangladesh & 63 \\
\hline Poland & 71 \\
\hline Nigeria & 83 \\
\hline Thailand & 100 \\
\hline South Africa & 114 \\
\hline Indonesia & 151 \\
\hline Mexico & 193 \\
\hline United States & 200 \\
\hline Brazil & 309 \\
\hline India & 349 \\
\hline
\end{tabular}

Source: Data is gathered from http://www.ashoka.org/ (19.06.2015) 


\section{MethodOLOGY}

Ashoka is the largest network of social entrepreneurs worldwide, with nearly 3,000 Ashoka fellows in 70 countries putting their system changing ideas into practice on a global scale. Founded by Bill Drayton in 1980, Ashoka has provided start-up financing, professional support services, and connections to a global network across the business and social sectors, and a platform for people dedicated to changing the world. Ashoka launched the field of social entrepreneurship and has activated multi-sector partners across the world that increasingly looks to entrepreneurial talent and new ideas to solve social problems [37].

Because of its importance and leader position Ashoka has been selected for the application part of this study. Website content analysis has been done in order to determine social entrepreneurs in Turkey and their characteristics, also comparisons have been made between world and Turkey about social entrepreneurship. There is no sampling method, because the study includes all of the 35 Ashoka fellows in Turkey (all population). Ashoka website is examined deeply to introduce social entrepreneurship in the world and Turkey.

From nomination to election as an Ashoka Fellow, candidates go through an extensive series of in-depth interviews, a judging panel, and a final executive board vote. International staff frequently makes site visits to evaluate candidates in their work environment. Nominees are rigorously questioned about practical implementation as well as personal background, values, motivations and aspirations. There is no age, education, class, race, or other such bars to election. Anyone who meets the five criteria is someone Ashoka wants. These are: (1) a new idea (a new solution or approach to a social problem), (2) being creative both as goal-setting visionaries and as problem solvers capable of engineering their visions into reality, (3) entrepreneurial quality (it defines leaders who see opportunities for change and innovation and devote themselves entirely to making that change happen), (4) social impact of the idea (Ashoka is only interested in ideas that it believes will change the field significantly and that will trigger nationwide impact), and (5) ethical fiber (if the entrepreneur is not trusted, the likelihood of success is significantly reduced) [38].

\section{FINDINGS}

In Table I and Table II number of Ashoka fellows according to countries, fields of work, and regions are summarized.

TABLE II: CLASSIFICATION OF ASHOKA FELLOWS WORLDWIDE

\begin{tabular}{|c|c|c|}
\hline Fields of Work & Number & \% \\
\hline Human Rights & $\mathbf{5 1 0}$ & \% 18,0 \\
\hline Economic Development & $\mathbf{5 5 8}$ & $\mathbf{\% 1 9 , 8}$ \\
\hline Civic Engagement & $\mathbf{4 8 6}$ & $\mathbf{\% ~ 1 7 , 2}$ \\
\hline Learning Education & $\mathbf{4 5 6}$ & $\mathbf{\% 1 6 , 2}$ \\
\hline Health & $\mathbf{4 6 9}$ & $\mathbf{\% ~ 1 6 , 6}$ \\
\hline Environment & $\mathbf{3 4 1}$ & $\mathbf{\% ~ 1 2 , 1}$ \\
\hline & & \\
\hline Region & Number & \% \\
\hline Asia & 799 & $\% 28,4$ \\
\hline South America & 638 & $\% 22,6$ \\
\hline Africa & 404 & $\% 14,3$ \\
\hline North America & 463 & $\% 16,4$ \\
\hline Europe & 411 & $\% 14,6$ \\
\hline MENA & 84 & $\% 3,0$ \\
\hline Global & 18 & $\% 0,6$ \\
\hline
\end{tabular}

Source: Data is gathered from http://www.ashoka.org/ (19.06.2015)

TABLE III(A): CHARACTERISTICS OF ASHOKA FELLOWS IN TURKEY

\begin{tabular}{|c|c|c|}
\hline $\begin{array}{l}\text { Name of Ashoka Fellow; } \\
\text { Year of Election }\end{array}$ & Field Of Work; Target Population & Organization \\
\hline Sengul Akcar; 2000 & Human Rights; Women & $\begin{array}{l}\text { Support for Women's Work (It is a unique, community-based foundation that } \\
\text { educates and empowers poor women and families, particularly in urban areas.) }\end{array}$ \\
\hline Nebahat Akkoc; 2000 & Human Rights; Families, Women & $\begin{array}{l}\text { KA-MER (It is an organization that both responds to women's immediate and } \\
\text { critical needs and increases awareness by women of their rights.) }\end{array}$ \\
\hline Victor Ananias; 2000 & $\begin{array}{l}\text { Environment; Citizen Sector } \\
\text { Organizations, Public }\end{array}$ & $\begin{array}{l}\text { Buğday Association for Supporting Ecological Living (Buğday ecological } \\
\text { movement has been tirelessly working to support, create and promote fair and } \\
\text { sustainable production-consumption patterns in Turkey and beyond.) }\end{array}$ \\
\hline Yusuf Kulca; 2001 & $\begin{array}{l}\text { Civic Engagement; Street Children, } \\
\text { Underserved Communities, Youth }\end{array}$ & $\begin{array}{l}\text { Children of Hope Foundation (It provides street children a place to stay, food to eat, } \\
\text { counseling, job possibilities, and help in returning to their families.) }\end{array}$ \\
\hline Nevin Eracar; 2003 & $\begin{array}{l}\text { Health; Children, Disabled } \\
\text { (Physical/Mental) }\end{array}$ & $\begin{array}{l}\text { Turkish Autism Association (It helps families, institutions, and society better } \\
\text { support and integrate people with autism.) }\end{array}$ \\
\hline Ercan Tutal; 2003 & $\begin{array}{l}\text { Human Rights; } \\
\text { Disabled (Physical/Mental), } \\
\text { Public }\end{array}$ & $\begin{array}{c}\text { Alternative Camp (It is an organization that offers disabled people and abilities an } \\
\text { opportunity to confront and overcome challenges through sports) }\end{array}$ \\
\hline $\begin{array}{l}\text { Gunesin Aydemir; } \\
2003\end{array}$ & $\begin{array}{c}\text { Environment; } \\
\text { Citizen Sector Organizations }\end{array}$ & $\begin{array}{l}\text { Networking for Nature Conservation in Turkey- A NatureNet (Gunesin Aydemir is } \\
\text { strengthening conservation efforts in Turkey by helping and supporting small but } \\
\text { capable nature conservation groups move forward with efficient and directed } \\
\text { initiatives that draw on the best strategies of a national network.) }\end{array}$ \\
\hline Yasemin Kilic; 2003 & $\begin{array}{l}\text { Economic Development; } \\
\text { Farmers/Sharecroppers }\end{array}$ & $\begin{array}{c}\text { Organic Farming (Yasemin Kilıç is popularizing organic farming to replace } \\
\text { harmful and expensive chemical fertilizers and pesticides and allow small-scale } \\
\text { farmers to stay in business.) }\end{array}$ \\
\hline
\end{tabular}

Source: Data is gathered from http://www.ashoka.org/ (24.06.2015)

TABLE III(B): CHARACTERISTICS OF ASHOKA FELLOWS IN TURKEY

\begin{tabular}{|c|c|c|}
\hline $\begin{array}{c}\text { Name of Ashoka Fellow; } \\
\text { Year of Election }\end{array}$ & $\begin{array}{c}\text { Field Of Work; Target } \\
\text { Population }\end{array}$ & Organization \\
\hline Ibrahim Betil; 2004 & Civic Engagement; Youth & $\begin{array}{c}\text { Community Volunteers Foundation- TOG (It creates opportunities for young adults } \\
\text { to contribute to positive social action through their own initiative.) }\end{array}$ \\
\hline Zeynep Uluer; 2004 & $\begin{array}{c}\text { Civic Engagement; Businesses, } \\
\text { Citizen Sector Organizations, } \\
\text { Volunteers }\end{array}$ & $\begin{array}{c}\text { Corporate Volunteer Association (Zeynep Uluer forges strong partnerships between } \\
\text { businesses and citizen organizations, helping corporate volunteers leverage their } \\
\text { professional skills to address the needs of poor communities across Turkey.) }\end{array}$ \\
\hline Omer Madra; 2004 & Civic Engagement; Public & Open Radio (It is an independent, listener-supported public radio, the first of its \\
\hline
\end{tabular}




\begin{tabular}{|c|c|c|}
\hline & & kind in Turkey.) \\
\hline Korhan Gumus; 2004 & $\begin{array}{l}\text { Civic Engagement; Communities, } \\
\text { Government, Public }\end{array}$ & $\begin{array}{l}\text { Human Settlements Association (He forms city watch groups-local coalitions of } \\
\text { citizens, municipal authorities, and experts - to guide urban planning in the cities } \\
\text { of Turkey, engaging in a participatory process to ensure the safety and health of } \\
\text { their communities.) }\end{array}$ \\
\hline Mustafa Sari; 2004 & $\begin{array}{l}\text { Environment; Communities, } \\
\text { Unions/Cooperatives }\end{array}$ & $\begin{array}{l}\text { Fisheries Department of Agriculture (It is demonstrating a new and promising } \\
\text { approach to protecting fish populations while sustaining the communities they } \\
\text { support.) }\end{array}$ \\
\hline $\begin{array}{l}\text { Nasuh Mahruki; } \\
\quad 2004\end{array}$ & $\begin{array}{l}\text { Civic Engagement; Communities, } \\
\text { Public, Volunteers }\end{array}$ & $\begin{array}{c}\text { AKUT Search and Rescue Team (Nasuh Mahruki draws on his experience in } \\
\text { outdoor search and rescue to orchestrate locally-managed volunteer response teams } \\
\text { to address natural disasters in Turkey and abroad.) }\end{array}$ \\
\hline Nazmi Ilıcalı; 2005 & $\begin{array}{l}\text { Economic Development; Families, } \\
\text { Farmers/Sharecroppers }\end{array}$ & $\begin{array}{c}\text { No Organization (Nazmi Ilicali is building agricultural cooperatives to seize new } \\
\text { markets, especially in Europe; curb migration to urban centers; and keep family } \\
\text { farming a viable livelihood.) }\end{array}$ \\
\hline Tahir Dadak; 2005 & $\begin{array}{l}\text { Civic Engagement; Communities, } \\
\text { Farmers/Sharecroppers }\end{array}$ & $\begin{array}{l}\text { Center of Development (Tahir Dadak aims to transform Turkey's citizen sector, } \\
\text { starting in rural Southeast Turkey, through sector-level improvements that enable } \\
\text { new talent, better investment opportunities, and a cohesive vision) }\end{array}$ \\
\hline $\begin{array}{l}\text { Naside Buluttekin; } \\
2006\end{array}$ & $\begin{array}{l}\text { Civic Engagement; Caregivers, } \\
\text { Children, Underserved } \\
\text { Communities }\end{array}$ & $\begin{array}{l}\text { No Organization (She is helping Turkey's poorest urban neighborhoods combat a } \\
\text { trend of rising crime by setting up daycare centers where mothers work with their } \\
\text { own children.) }\end{array}$ \\
\hline Halime Güner; 2006 & $\begin{array}{l}\text { Civic Engagement; Communities, } \\
\text { Journalists, Women }\end{array}$ & $\begin{array}{l}\text { Flying Broom (It is giving voice to Turkish women nationwide by developing a } \\
\text { network of female journalists covering women's issues.) }\end{array}$ \\
\hline $\begin{array}{l}\text { Arzum Meleksoy; } \\
2007\end{array}$ & $\begin{array}{l}\text { Civic Engagement; Businesses, } \\
\text { Citizen Sector Organizations, } \\
\text { Public }\end{array}$ & $\begin{array}{l}\text { alisbagis.com.tr (It is an Internet platform and community network enables } \\
\text { individuals and businesses to work together in supporting the most innovative } \\
\text { social organizations and development programs.) }\end{array}$ \\
\hline
\end{tabular}

Source: Data is gathered from http://www.ashoka.org/ (24.06.2015)

TABLE III(C): CHARACTERISTICS OF ASHOKA FELLOWS IN TURKEY

\begin{tabular}{|c|c|c|}
\hline $\begin{array}{l}\text { Name of Ashoka Fellow; } \\
\text { Year of Election }\end{array}$ & $\begin{array}{l}\text { Field Of Work; Target } \\
\text { Population }\end{array}$ & Organization \\
\hline Berna Yagci; 2007 & $\begin{array}{l}\text { Civic Engagement; Children, } \\
\text { Women }\end{array}$ & $\begin{array}{l}\text { Silk Road Women's Cooperative (It is a concrete method of generating income } \\
\text { through an official cooperative where women produce handicrafts and artisan } \\
\text { soaps.) }\end{array}$ \\
\hline Nejat Unlu; 2007 & $\begin{array}{l}\text { Human Rights; Communities, } \\
\text { HIV/AIDS Affected }\end{array}$ & $\begin{array}{l}\text { Positive Living (Nejat Unlu has designed the first comprehensive care and } \\
\text { support system for Turkish citizens infected with HIV/AIDS.) }\end{array}$ \\
\hline Selma Demirelli; 2007 & $\begin{array}{l}\text { Economic Development; Children, } \\
\text { Unions/ Cooperatives, Women }\end{array}$ & $\begin{array}{c}\text { Water Lily Women's Cooperative (It is Turkey's first women's housing } \\
\text { cooperative to empower women as property owners with full citizenship and } \\
\text { financial stability.) }\end{array}$ \\
\hline Senem Gul; 2007 & $\begin{array}{l}\text { Economic Development; } \\
\text { Immigrants/Communities, } \\
\text { Underserved Communities, } \\
\text { Women } \\
\end{array}$ & $\begin{array}{l}\text { First Step Women's Cooperative (It brings a diverse group of women together, } \\
\text { providing them with basic education, training, and jobs, and pushing them to } \\
\text { take responsibility and leadership for improving the world) }\end{array}$ \\
\hline Egemen Yilgur; 2008 & $\begin{array}{l}\text { Human Rights; Journalists, } \\
\text { Underserved Communities, Youth }\end{array}$ & $\begin{array}{c}\text { Cingeneyiz (This web platform gives Romanis a voice and an opportunity to } \\
\text { counter negative sterotypes and present a postive and accurate image of their } \\
\text { culture) }\end{array}$ \\
\hline Bedriye Hülya; 2012 & Economic Development; Women & $\begin{array}{c}\text { b-Fit (It uses a unique model that combines access to sports and entrepreneurship } \\
\text { as vehicles to promote gender equality, education, entrepreneurship, and } \\
\text { empowerment of women and girls in Turkey.) }\end{array}$ \\
\hline Tülin Akın; 2012 & $\begin{array}{l}\text { Economic Development; } \\
\text { Farmers/Sharecroppers }\end{array}$ & $\begin{array}{l}\text { Tarimsal Pazarlama (Tülin Akın is building a platform of information } \\
\text { technologies to act as an enabling architecture for Turkey's three million farmer } \\
\text { families to fully and actively participate in the economy and society.) }\end{array}$ \\
\hline Şehnaz Layıkel; 2012 & Health; Mentally ill & $\begin{array}{l}\text { Human Rights in Mental Health Initiative-RUSIHAK (It empowers individuals } \\
\text { with mental disabilities and their families by helping them become } \\
\text { decision-makers, bringing full citizenship to a strategically important group that } \\
\text { has too often faced systematic discrimination, social isolation, and poor quality } \\
\text { of life.) }\end{array}$ \\
\hline Hayrettin Karaca; 2013 & $\begin{array}{l}\text { Environment; Children, } \\
\text { Communities, } \\
\text { Farmers/Sharecroppers }\end{array}$ & $\begin{array}{l}\text { The Turkish Foundation for Combating Soil Erosion, for Reforestation and the } \\
\text { Protection of Natural Habitats-TEMA (Hayrettin Karaca has dedicated his life to } \\
\text { tireless advocacy and support for the protection of soil and natural habitats, } \\
\text { combining successful entrepreneurship with effective environmental leadership) }\end{array}$ \\
\hline Zafer Kıraç; 2013 & Human Rights; Prisoners & $\begin{array}{c}\text { Civil Society in the Penal System Association (Bringing some of Turkey's } \\
\text { leading civil organizations (COs) and universities into the prisons, Civil Society } \\
\text { in the Penal System (CISST) acts as a platform to provide social and educational } \\
\text { support to prisoners and prison personnel.) }\end{array}$ \\
\hline Serra Titiz; 2013 & Economic Development; Youth & $\begin{array}{l}\text { Future is Brighter (It empowers and encourages youth self-determination with } \\
\text { the ability to make informed education, career choices and life choices.) }\end{array}$ \\
\hline
\end{tabular}

Source: Data is gathered from http://www.ashoka.org/ (24.06.2015)

TABLE III(D): CHARACTERISTICS OF ASHOKA FELLOWS IN TURKEY

\begin{tabular}{|c|c|c|}
\hline $\begin{array}{c}\text { Name of Ashoka Fellow; } \\
\text { Year of Election }\end{array}$ & Field Of Work; Target Population & Organization \\
\hline Ittr Erhart; 2014 & $\begin{array}{c}\text { Civic Engagement; Citizen Sector } \\
\text { Organizations, Public, Volunteers }\end{array}$ & $\begin{array}{c}\text { Adim Adim(It creats a movement of role model citizens and organizations } \\
\text { who are convinced to create social change, step by step.) }\end{array}$ \\
\hline Celal Karadoğan; 2014 & $\begin{array}{c}\text { Civic Engagement, Health; Disabled, } \\
\text { Underserved Communities, Youth }\end{array}$ & $\begin{array}{c}\text { Youth With Disabilities Sports Club (It creates spaces and experiences for } \\
\text { youth with and without disabilities to overcome their barriers, to } \\
\text { experience the power of solidarity and to realize their full potentials, both }\end{array}$ \\
\hline
\end{tabular}




\begin{tabular}{|c|c|c|}
\hline & physically and mentally.) \\
\hline Emrah Kırımsoy; 2014 & Civic Engagement; Children & $\begin{array}{c}\text { Gundem Cocuk Dernegi (Agenda Children seeks to do exactly what the } \\
\text { name entails: to put children's will and issues on Turkey's busy agenda.) }\end{array}$ \\
\hline Azize Leygara; 2014 & $\begin{array}{c}\text { Cuman Rights; Children, Displaced } \\
\text { People/Refugees/Migrants }\end{array}$ & $\begin{array}{c}\text { Cocuklar Ayn Catı Altında- CAÇA (ÇAÇ's efforts have been } \\
\text { instrumental in diminishing the number of street children in Diyarbakır by } \\
\text { half in the past five years.) }\end{array}$ \\
\hline Renay Onur; 2014 & $\begin{array}{c}\text { Civic Engagement; Citizen Sector } \\
\text { Organizations, Public }\end{array}$ & $\begin{array}{c}\text { Adim Adim (It creats a movement of role model citizens and organizations } \\
\text { who are convinced to create social change, step by step.) }\end{array}$ \\
\hline
\end{tabular}

In Table IV, number and percentage of Ashoka fellows between world and Turkey are compared according to their target populations.

TABLE IV: COMPARISON OF TARGET POPULATIONS BETWEEN WORLD AND TURKEY

\begin{tabular}{|l|c|c|c|c|}
\hline Target Population & $\begin{array}{c}\text { Number } \\
\text { in World }\end{array}$ & $\begin{array}{c}\% \text { in } \\
\text { World }\end{array}$ & $\begin{array}{c}\text { Number } \\
\text { in Turkey }\end{array}$ & $\begin{array}{c}\% \text { in } \\
\text { Turkey }\end{array}$ \\
\hline Businesses & 199 & $\% 4,1$ & 2 & $\% 2,7$ \\
\hline Caregivers & 76 & $\% 1,6$ & 1 & $\% 1,3$ \\
\hline Children & 363 & $\% 7,5$ & 7 & $\% 9,4$ \\
\hline $\begin{array}{l}\text { Citizen Sector } \\
\text { Organizations }\end{array}$ & 337 & $\% 7,0$ & 6 & $\% 8,1$ \\
\hline Communities & 843 & $\% 17,4$ & 9 & $\% 12,2$ \\
\hline $\begin{array}{l}\text { Disabled } \\
\text { (Physical/Mental) }\end{array}$ & 190 & $\% 3,9$ & 4 & $\% 5,4$ \\
\hline Families & 239 & $\% 4,9$ & 2 & $\% 2,7$ \\
\hline $\begin{array}{l}\text { Farmers/ } \\
\text { Sharecroppers }\end{array}$ & 255 & $\% 5,3$ & 5 & $\% 6,7$ \\
\hline Government & 319 & $\% 6,6$ & 1 & $\% 1,3$ \\
\hline HIV/AIDS Affected & 65 & $\% 1,3$ & 1 & $\% 1,3$ \\
\hline Immigrants & 54 & $\% 1,1$ & 2 & $\% 2,7$ \\
\hline Journalists & 63 & $\% 1,3$ & 2 & $\% 2,7$ \\
\hline Prisoners & 50 & $\% 1,0$ & 1 & $\% 1,3$ \\
\hline Public & 395 & $\% 8,2$ & 8 & $\% 10,8$ \\
\hline Street Children & 53 & $\% 1,1$ & 1 & $\% 1,3$ \\
\hline $\begin{array}{l}\text { Underserved } \\
\text { Communities }\end{array}$ & 453 & $\% 9,4$ & 5 & $\% 6,7$ \\
\hline Unions/Cooperatives & 40 & $\% 0,8$ & 2 & $\% 2,7$ \\
\hline Volunteers & 66 & $\% 1,4$ & 3 & $\% 4,0$ \\
\hline Women & 338 & $\% 7,0$ & 7 & $\% 9,4$ \\
\hline Youth & 437 & $\% 9,0$ & 5 & $\% 6,7$ \\
\hline Source Da & & & \\
\hline
\end{tabular}

Source: Data is gathered from http://www.ashoka.org/ (Target populations that do not take place in Turkey are not included in this table). (20.06.2015)

There are 35 social entrepreneurs in Turkey who are in Ashoka fellows list. They have been chosen after an extensive series of in-depth interviews, a judging panel, and a final executive board vote as all of the fellows. These 35 individuals and their characteristics are introduced in Table III (a,b,c,d) and Table V:

TABLE V: ClASSIFICATION OF ASHOKA FELLOWS IN TURKEY

\begin{tabular}{|l|l|l|l|}
\hline Gender & Number $(\%)$ & Field of Work & Number (\%) \\
\hline Women & $19(\% 54,3)$ & Civic Engagement & $14(\% 40)$ \\
\hline Men & $16(\% 45,7)$ & $\begin{array}{l}\text { Economic } \\
\text { Development }\end{array}$ & $7(\% 20)$ \\
\hline & & Human Rights & $7(\% 20)$ \\
\hline & & Environment & $4(\% 11,4)$ \\
\hline & & Health & $3(\% 8,6)$ \\
\hline & & Learning/Education & 0 \\
\hline
\end{tabular}

Source: Data is gathered from http://www.ashoka.org/ (20.06.2015)

\section{CONSCLUSIONS AND Discussion}

Since social entrepreneurship is an activity that addresses social pains that are not adequately resolved by the state, civil society, or the market, a higher prevalence of social entrepreneurship in areas with higher levels of social pains (e.g., poverty, environmental degradation, war, or illiteracy), higher levels of state failures (e.g., corruption, education, or health provision) or lower levels of civil society involvement (e.g., trade unions, social dialogue, or volunteering) might be expected. But as a result of higher levels of social pains, people must pay more attention to survival, and would thus find themselves in a context where payoffs favor regular entrepreneurship above social entrepreneurship. So also lower numbers of social entrepreneurs in developing countries might be expected [39].

We can see from Table I that Belize, Benin, Botswana, China, Guinea-Bissau, Hong Kong S.A.R. China, Iceland, Italy, Latvia, Libya, Malawi, Niger, Portugal, and United Arab Emirates has least social entrepreneurs in Ashoka. Nigeria, Thailand, South Africa, Indonesia, Mexico, United States, Brazil, and India are countries that include most social entrepreneurs. These findings are consistent with the previous citation which says "both lower and higher numbers of social entrepreneurs in developing countries might be expected". As a result it is not possible to say developed countries have more social entrepreneurs than underdeveloped countries and vice versa. For instance, both Denmark and Afghanistan have 3 Ashoka fellows, both Japan and Nicaragua have 4 Ashoka fellows, both Sweden and Tanzania have 6 Ashoka fellows. But Worldbank 2014 Data [40] shows that Denmark is $13^{\text {rd }}$ while Afghanistan is $146^{\text {th }}$, Japan is $22^{\text {nd }}$ while Nicaragua is $120^{\text {th }}$, Sweden is $12^{\text {th }}$ while Tanzania is $140^{\text {th }}$ country acoording to their GNI per capita based on purchasing power parity.

If we look at all countries in Table I, it will be seen that Turkey is somewhere in the middle, because of its 35 Ashoka fellows. But this number do not indicate whether Turkey is developed or not as explained before (in the same GNI per capita list Turkey is the $51^{\text {st }}$ country).

Social entrepreneurs' fields of work have different percentages in the world and Turkey. According to Table II in the world, most widespread work fields are economic development $(\% 19,8)$, human rights $(\% 18)$, and civic engagement $(\% 17,2)$. In contrast; civic engagement $(\% 40)$ is dominant in Turkey according to Table V. Economic development (\%20), and human rights (\%20) follow it. It is interesting that there is not any social entrepreneur working on learning/education in Turkey while world percentage of this work field is \%16,2. Although "education" is one of the most important problem in Turkey according to many citizen, there is a social entrepreneurship gap in this field.

When we look at number of Ashoka fellows in Turkey, sharp decreases can be seen between 2001-2003 and 2008-2012 (Table III a, c). Because Turkey experienced very serious economic and political crisis in November 2000 and in February 2001. In 2008 the world economy faced its most dangerous crisis since the Great Depression of the 1930s [41], all of the world including Turkey was affected by this global 
financial crisis for several years. So it can be said that economic stability affects number of social entrepreneurs at least in Turkey. This is consistent with Maslow's hierarchy of needs model, because if people have difficulty to meet their physiological needs they will not be able to think of helping others, it is an upper step need.

If we compare social entrepreneurs' target populations in the world and Turkey (Table IV), it can be seen that "communities" is the most frequent target both in the world $(\% 17,4)$ and Turkey $(\% 12,2)$. In the world underserved communities $(\% 9,4)$ and youth targets $(\% 9,0)$ follows it, but in Turkey, public $(\% 10,8)$, women $(\% 9,4)$, and children targets $(\% 9,4)$ follow. This shows the priorities of social needs in Turkey. Highest difference between the world and Turkey about percentage distribution of target populations is "government" target (world \% 6,6; Turkey \%1,3). This can be explained by Turkish culture with high power distance which means that less powerful members (Turkish citizens) expect and accept that power is distributed unequally [42]. So limited numbers of people perceive government as a target population in Turkey.

The findings about gender of social entrepreneurs in Turkey are surprising. Because number of women and men social entrepreneurs in Turkey are almost equal (Table V) although there are very few women entrepreneurs against men in Turkey's economic enterprises. This should be emphasized because of the incorrect universal perception of Turkish women. Unfortunately most of the foreigners believe that Turkey is a primitive country and women are out of life.

This study is not without limitations. For instance, only Ashoka fellows have been researched, but there are other social entrepreneurs worldwide apart from Ashoka. Social entrepreneurship is still an emerging area for academic research. Because of time limitations this study couldn't go beyond content analysis. Using qualitative methods such as interviews with social entrepreneurs can produce meaningful results. Future researches can also focus on a single target population or fields of work for social entrepreneurs and analyze it in detail. This study analyzed number and percentage distributions, however I didn't make any evaluation about the effiency and effectiveness of these social enterprises which can be offered for future researches.

\section{REFERENCES}

[1] M. T. Dacin, P. A. Dacin, and P. Tracey, "Social entrepreneurship: A critique and future directions," Organization Science, vol. 22, no. 5, pp. 1203-1213, 2011.

[2] R. Spear, "Social entrepreneurship: A different model?" International Journal of Social Economics, vol. 33, no. 5/6, pp. 399-410, 2006.

[3] C. A. Hemingway, "Personal values as a catalyst for corporate social entrepreneurship," Journal of Business Ethics, vol. 60, pp. 233-249 2005.

[4] S. M. Razavi, M. Asadi, H. M. Esfandabadi, and H. Ekbatani, "Design patterns barriers to social entrepreneurship: An application of grounded theory," Research on Humanities and Social Sciences, vol. 4, no. 16, 2014.

[5] J. Weerawardena and G. S. Mort, "Investigating social entrepreneurship: A multidimensional model," Journal of World Business, vol. 41, pp. 21-35, 2006.

[6] J. Mair and I. Marti, "Social entrepreneurship research: A source of explanation, prediction, and delight," Journal of World Business, vol. 41, pp. 36-44, 2006.

[7] C. Seelos and J. Mair, "Social entrepreneurship: Creating new business models to serve the poor," Business Horizons, vol. 48, pp. 241-246, 2005.
[8] R. Harding, "Understanding social entrepreneurship," Industry \& Higher Education, vol. 8, pp. 73-84, 2007.

[9] B. Cookj, C. Dodds, and W. Mitchell, "Social entrepreneurship false premises and dangerous forebodings, Australian Journal of Social Issues, vol. 38, no. 1, pp. 57-72, 2003.

[10] P. B. McInerney, "Reconciling altruism and pragmatism: Social entrepreneurship and the production of new organizational forms," presented at the American Sociological Association 2005 Annual Meeting, pp. 1-24, 2005.

[11] R. Moorthy and S. Annamalah, “Consumers' perceptions towards motivational intentions of social entrepreneurs in Malaysia," Rev. Integr. Bus. Econ. Res., vol. 3, no. 1, pp. 257-286, 2014.

[12] A. M. Peredo and M. Mclean, "Social entrepreneurship: A critical review of the concept," Journal of World Business, vol. 41, pp. 56-65, 2006.

[13] J. L. Thompson, "The world of the social entrepreneur," The International Journal of Public Sector Management, vol. 15, issue 5, pp. 412-431, 2002.

[14] J. Thompson and B. Doherty, "The diverse world of social enterprise a collection of social enterprise stories," International Journal of Social Economics, vol. 33, no. 5/6, pp. 361-375, 2006.

[15] J. Austin, H. Stevenson, and J. Wei-Skillern, "Social and commercial entrepreneurship: Same, different or both?" Entrepreneurship Theory and Practice, vol. 30, issue 1, pp. 1-22 2006.

[16] J. Roper and G. Cheney, "Leadership, learning and human resource management The meanings of social entrepreneurship today," Corporate Governance, vol. 5, no. 3, pp. 95-104, 2005.

[17] M. Tamer. (December 2006). İzmir'in Efesi Mükemmel Sosyal Girişimci. [Online]. Available: http://www.turizmhaberleri.com/KoseYazisi.asp?ID=121

[18] D. M. Slyke and H. K. Newman, "Venture philanthropy and social entrepreneurship in community redevelopment," Nonprofit Management \& Leadership, vol. 16, no. 3, pp. 345-368, 2006.

[19] S. A. Hibbert, G. Hogg, and T. Quinn, "Social entrepreneurship: Understanding consumer motives for buying The Big Issue," Journal of Consumer Behavior, vol. 4, no. 3, pp. 159-172, 2005.

[20] G. N. Prabhu Social entrepreneurial leadership, Career Development International, vol. 4/3, pp. 140-145, 1999

[21] R. L. Martin and S. Osberg "Social entrepreneurship: The case for definition," Stanford Social Innovation Review, pp. 29-39, Spring 2007.

[22] P. Hartigan, "It's about people, not profit," Business Strategy Review, pp. 42-45, Winter 2006.

[23] H. L. Rahim and S. Mohtar, "Social entrepreneurship: A different perspective," International Academic Research Journal of Business and Technology, vol. 1, no. 1, pp. 9-15, 2015.

[24] A. W. Montgomery, P. A. Dacin and M. T. Dacin, "Collective social entrepreneurship: Collaboratively shaping social good," Journal of Business Ethics, vol. 111, pp. 375-388, December 2012.

[25] R. L. Korosec and E. M. Berman "Municipal Support for Social Entrepreneurship," Public Administration Review, pp. 448-462, 2006

[26] Sen, P. Ashoka's big idea: Transforming the world through social entrepreneurship, Futures, vol. 39, pp. 534-553, 2007.

[27] Social Entrepreneur. [Online]. Available: https://www.ashoka.org/social_entrepreneur

[28] R. L. Korosec and E. M . Berman, "Municipal support for social entrepreneurship," Public Administration Review, pp. 448-462, 2006.

[29] A. S. Samer, "Social entrepreneurship: Definition and boundaries," Technology Innovation Management Review, pp. 22-27, February 2012.

[30] H. Denizalp, Toplumsal Dönüşüm Iç̧in Sosyal Girişimcilik Rehberi, Odak Ofset Matbaacılık, Ankara (Sivil Toplum Geliştirme Merkezi), 2007.

[31] S. A. Waddock and J. E. Post, "Social entrepreneurs and catalytic change," Public Administration Review, vol. 51, no. 5, pp. 393-401, 1991.

[32] J. G. Dees, "Taking social entrepreneurship seriously," Transaction Social Science and Modern Society, vol. 44, no. 3, pp. 24-31, 2007.

[33] M. Sharir and M. Lerner, "Gauging the success of social ventures initiated by individual social entrepreneurs," Journal of World Business, vol. 41, pp. 6-20, 2006.

[34] J. Thompson, G. Alvy and A. Lees, "Social entrepreneurship - a new look at the people and the potential," Management Decision, vol. 38, no. 5, pp. 328-338, 2000.

[35] R. Kaufman, A. Avgar, and J. Mirsky, "Social entrepreneurship in crisis situations," The International Journal of Diversity in Organizations, Communities and Nations, vol. 7, no. 3, pp. 227-232, 2007. 
[36] E. Shaw and S. Carter, "Social entrepreneurship Theoretical antecedents and empirical analysis of entrepreneurial processes and outcomes," Journal of Small Business and Enterprise Development, vol. 14 , no. 3, pp. 418-434, 2007.

[37] Ashoka Innovators For The Public. [Online]. Available: https://www.ashoka.org/about

[38] Selection criteria. [Online]. Available: https://www.ashoka.org/support/criteria

[39] J. Lepoutre, R. Justo, S. Terjesen, and N. Bosma, "Designing a global standardized methodology for measuring social entrepreneurship activity: The global entrepreneurship monitor social entrepreneurship study," Small Bus Econ, vol. 40, pp. 693-714, 2013.

[40] GNI per capita, PPP. [Online]. Available: http://data.worldbank.org/indicator/NY.GNP.PCAP.PP.CD

[41] The financial crisis of 2008: Year in review 2008. [Online]. Available: http://www.britannica.com/topic/Financial-Crisis-of-2008-The-14842 64

[42] What about Turkey? http://geert-hofstede.com/turkey.html

[Online]. Available:

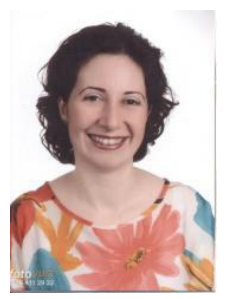

study is marketing.

She worked in several universities such as Çanakkale Onsekiz Mart University (2005-2008), Bahcesehir University (2008-2009), and Okan University (2010-2013). Since 2014 she works at Nisantasi University, Faculty of Economics, Administrative and Social Sciences, İstanbul, Turkey. Current and previous research interests are online retailing, brand management, marketing strategies, corporate social responsibility, and entrepreneurship

Assist. Prof. İnci received an honor award with "The Success Story of Arçelik A.S.." at II. International Strategic Management Conference, 8-10 June 2006, İstanbul (as a coauthor). She has several publications such as "Conceptual approach to the studies of marketing strategies and positioning on destination marketing," IIstanbul Journal of Social Sciences, vol. 1, no. 1 , 2012 (as a coauthor). 